Uludag Univ. J. Fac. Vet. Med. 32 (2013), 2: 11-17

\title{
Effect of Yeast Culture on Growth Performance, Haematological and Biochemical Indices of New Zealand White Rabbits
}

\author{
Nilay SEYIDOGLU ${ }^{1}$
}

\author{
Nurten GALIP ${ }^{1}$
}

Geliş Tarihi: 03.04.2014

Kabul Tarihi: 30.04 .2014

\author{
Füsun AK SONAT ${ }^{1}$
}

\begin{abstract}
Effect of Sacchoromyces cerevisiae live yeast culture on growth performance, haematological and biochemical indices of rabbits was studied with 6-7 weeks old New Zealand white rabbits. Thirty male rabbits were divided equally into 3 groups; I.control group (basal diet), II.group (added $S$. cerevisiae, $2 \mathrm{~g} / \mathrm{kg}$ diet) and III.group (added S. cerevisiae, $4 \mathrm{~g} / \mathrm{kg}$ diet). Blood samples were obtained via ear venipuncture on the 85 th day of feeding yeast of rabbits. No significant difference was observed in blood composition and growth performance by $S$. cerevisiae. Leukocyte, haematocrit and haemoglobin concentration slightly increased while serum cholesterol slightly decreased by $S$. cerevisiae $(\mathrm{p}>0.05)$. However, monocyte count $(\mathrm{p}<0.05)$ increased in groups fed 2 $\mathrm{g} / \mathrm{kg}$ and $4 \mathrm{~g} / \mathrm{kg}$ S. cerevisiae. Yeast culture has a positive effect on immune system. Increased monocyte value by S. cerevisiae is beneficial in improving the immunity. On the other hand, other parameters of natural and induced immune system may be expressed to determine. So, more studies would be necessary to elucidate the effects of supplementing yeast on immunity and determine the optimum dietary concentration in animals.
\end{abstract}

Key Words: Rabbits, yeast culture, blood composition, growth performance.

\section{Mayanın Yeni Zellanda Beyaz Tavşanlarında Büyüme Performansı, Hematolojik ve Biyokimyasal Parametreleri Üzerine Etkileri}

Özet: Bu çalışmada, 6-7 haftalık yaştaki Yeni Zellanda Beyaz tavşanlarında Saccharomyces cerevisiae canlı maya kültürünün büyüme performansı, hematolojik ve biyokimyasal parametreleri üzerine etkileri araştırıldı. $\mathrm{Bu}$ amaçla, 30 erkek tavşan 3 gruba ayrıldi. I. Grup; standart tavşan diyeti ile beslenen kontrol grubu, II. Grup; yemlerine $2 \mathrm{~g} / \mathrm{kg}$ dozda $S$. cerevisiae ilave edilmiş maya grubu, III. Grup ise yemlerine $4 \mathrm{~g} / \mathrm{kg}$ dozda $S$. cerevisiae ilave edilmiş maya grubudur. Maya ile beslemenin 85. gününde tavşanların kulak yeninden kan örnekleri alındı. S. cerevisiae'nın kan parametreleri ve büyüme performansı üzerine istatistiksel olarak anlamlı bir etkisi bulunamadı. Ancak lökosit sayısı, hematokrit değeri ve hemoglobin konsantrasyonu açısından anlamlı olmasa da bir artış ve serum kolesterol seviyesinde de bir düşüş saptandı ( $>0.05$ ). Bununla beraber $2 \mathrm{~g} / \mathrm{kg}$ ve $4 \mathrm{~g} / \mathrm{kg} \mathrm{S}$. cerevisiae ile beslenen gruplarda monosit sayısı açısından anlamlı bir artış saptandı $(\mathrm{p}<0.05)$. Mayanın immun sistem üzerine pozitif bir etkisi sözkonusudur. S. cerevisiae tarafından artan monosit değerinin bağışıklığı güçlendirici etkisi bulunmaktadır. Öte yandan doğal bağışıklık ve sonradan kazanılmış bağışıklık sistemiyle ilgili diğer parametrelerin de değerlendirilmesi yapılabilir. Bu nedenle hayvanlarda en iyi diyet konsantrasyonunu ve bağışılık üzerinde maya ilavesinin etkisini belirlemek için daha fazla çalışmaya ihtiyaç vardır.

Anahtar Kelimeler: Tavşan, maya kültürü, kan parametreleri, büyüme performansı. 


\section{Introduction}

Single cell proteins are a group of microorganisms including unicellular algae, fungi, bacteria, cyanobacteria, and yeast. Yeasts are a good source of protein. The yeast, Saccharomyces cerevisiae, contains valuable proteins, vitamin B and important trace minerals. Also, It has the cell wall products, beta glucan and mannanoligosaccharide which use for dietary supplement in animals, nowadays. Nutritional feasibility and benefit of dietary S. cerevisiae has been observed from studies with animals $^{26,24,31,33,3,38,29,22}$

The yeast, $\mathbf{S}$. cerevisiae, is a well-known probiotic with positive effects of the growth performances and prevention diseases ${ }^{19} . S$. cerevisiae has been shown to survive living in the gastrointestinal tract while eliminating the potentially pathogenic bacteria residing. Since yeast does not colonize the gastrointestinal tract permanently, it is used as a probiotic ${ }^{4}$. It has been postulated that probiotics binds to bile acids in the intestinal lumen, which results in a reduced bile acid pool back to the liver. This binding action stimulates the production of more bile acids derived from cholesterol that is either made endogenously or captured from the circulation. This action may reduce serum cholesterol level ${ }^{13}$. There are many conflicting studies on the effect of $S$. cerevisiae on serum lipid profile in animals. Although some of studies showed cholesterol reduction ${ }^{33,38}$, the others demonstrated no benefits ${ }^{19,30,43}$.

The addition of $S$. cerevisiae stimulates and maintains the immun system. In vitro as well as in vivo studies in animals and humans show that especially $\beta$-glucans derived from yeast have immune modulating properties. The stimulatory effects of yeast $\beta$-glucan on leukocytes, monocytes and neutrophils have been demonstrated in rabbits ${ }^{14}$. On the other hand, Onifade et al. ${ }^{28}$ and Onifade ${ }^{29}$ reported a positive correlation between dietary levels of S. cerevisiae with the haematological indices like haematocrit, erythrocytes and haemoglobin in rabbit and broiler chickens. They proposed that these correlations may be an additional mechanism of growth promotion by supplemental yeast.

This research was aimed to evaluate the combined effect of $S$. cerevisiae on growth performance, hematological and biochemical parameters. Also, there are many inconsistent data about the effects of $S$. cerevisiae in animals. So, this study contributes to an understanding of the literature about $S$. cerevisiae.

\section{Materials and Methods}

\section{Animals, groups and feeding}

Thirty 6-7 weeks old New Zealand white rabbits (mean body weight, $662 \mathrm{~g}$ ) were randomly allocated to three groups and housed individually in cages with facilities for feeding and watering. Food and water was offered ad libitum to the rabbits throughout the 12 weeks trial. Rabbits were separated into three equal groups as control and other two as treatment 1 and 2. Control group was fed basal diet while treatment 1 fed $2 \mathrm{~g} / \mathrm{kg}$ yeast and treatment 2 fed $4 \mathrm{~g} / \mathrm{kg}$ yeast (Yea-Sacc ${ }^{1026}$, Saccharomyces cerevisiae live yeast culture Altech, Nicholasville: $5 \times 10^{9} \mathrm{CFU} / \mathrm{g}$ ). Basal diet (pelleted) was designed to meet maintenance requirements (27) for rabbits. Chemical composition of basal diet (DM\%) was dry mater $90.04 \%$, crude fiber $10.00 \%$, crude protein $17.00 \%$, ether extract $4.86 \%$ and ash $6.93 \%$ (Table 1). Chemical analyses of basal diet were carried according to $\mathrm{AOAC}^{2}$

The experimental protocols were approved by the Animal Care and Use Committee of Uludag University and are in accordance with National Institute of Health Guide for the Care and Use of Laboratory Animals.

\section{Measurements}

During the experiment, body weight, body weight gain and food intake of each rabbit was determined every 15 days. Blood samples were collected by ear venipuncture on the 85 th day of the trial from rabbits. Blood samples were collected in EDTA-treated tubes for haemotological parameters, while samples for serum clinical parameters were collected without anticoagulant tubes. Erythrocyte, leukocyte and haematocrit values were estimated according to the methods reported by $\mathrm{Jain}^{21}$. Also MCV (mean corpuscular volume), $\mathrm{MCH}$ (mean corpuscular haemoglobin), and MCHC (mean corpuscular haemoglobin concentration), were mathematically calculated according to Jain ${ }^{21}$. The levels of haemoglobin were measured spectrophotometrically by the cyanmethemoglobin method of Cannon ${ }^{7}$. Reduced glutathione (GSH) in erythrocytes was determined spectrophotometrically (Shimadzu UV 1201 V, Japan) according to procedure adopted by Beutler et al. ${ }^{5}$. Serum clinical parameters were determined with "Technicon Dax 72" autoanalyzer (Miles Inc., Tarrytown, NY, USA). The whole blood $\mathrm{Na}^{+}$ and $\mathrm{K}^{+}$concentrations were analyzed by flame photometry. 
Table 1. Chemical composition of basal diet (DM \%)

Tablo 1. Bazal diyetin kimyasal içeriği (\%Kuru Madde)

\begin{tabular}{|lc|}
\hline & Diet \\
\hline Dry Mater & 90.04 \\
Crude Fibber \%* & 10.00 \\
Crude Protein \%* & 17.00 \\
Ether Extractives \%* & 4.86 \\
Ash & 6.93 \\
\hline
\end{tabular}

*Bases of \% Dry Matter

*Kuru maddeden baz alınmıştır.

\section{Statistical analysis}

Statistical analyses were performed with SPSS $^{39}$. Data was tested for normality distribution and variance homogeneity assumptions. All the values were grouped and the means and standard errors were calculated. One-way ANOVA was applied to Biochemical indices and Growth parameters (body weight, body weight gain and food intake) to examine the differences among groups. Differences were considered significant at $p<0.05$. If the difference among groups was provided to be significant $(p<0.05)$, differences evaluated group by Tukey's test ${ }^{12}$. On the other hand, in nonhomogenous groups, differences between means were analysed by Kruskal Wallis and following Mann Whitney U test between groups one by one $^{9}$.

\section{Results}

Biochemical indices of the three experimental groups (control, thr1, thr2) are presented in Table 2; there was no significant $(p>0.05)$ changes among groups. However the serum cholesterol value tended to be lower in rabbits fed yeast. Nevertheless there was no significant changes in the hematological parameters, as shown in Table 3; only the blood monocytes count was significantly $(\mathrm{p}<0.05)$ higher in group 1 and group 2, and leukocyte, hematocrit and hemoglobin concentrations slightly increased. Performance parameters of the control and experimental groups are presented in Figure 1, 2 and 3 ; there were no significant changes in the growth performances of the groups. The insignificant results may be due to the inefficient dose of S. cerevisiae in the present study.
Table 2. Biochemical indices of rabbits in Control and Experimental Groups $($ mean \pm SE, $n=30)$.

Tablo 2. Kontrol ve Deney gruplarının serum biyokimyasal değerleri (ortalama \pm standart hata, $n=30$ )

\begin{tabular}{|lccc|}
\hline Biochemical Indices & \multicolumn{3}{l}{ Yeast $(\mathrm{g} / \mathrm{kg})$} \\
\cline { 2 - 4 } (Serum) & 0 & 2 & 4 \\
\cline { 2 - 4 } & Control & Treatment 1 & Treatment 2 \\
\hline Phosphorus (mg/dl) & $8.6 \pm 0.4$ & $8.9 \pm 0.4$ & $8.8 \pm 0.3$ \\
Calcium (mg/dl) & $10.2 \pm 0.6$ & $10.5 \pm 0.6$ & $10.8 \pm 0.5$ \\
Potassium (mEq/l) & $17.1 \pm 0.9$ & $21.4 \pm 3.0$ & $20.1 \pm 1.5$ \\
Sodium (mEq/l) & $144.2 \pm 6.4$ & $135.10 \pm 7.3$ & $149.8 \pm 2.5$ \\
Cholesterol (mg/dl) & $72.7 \pm 9.3$ & $73.7 \pm 9.32$ & $60.5 \pm 5.7$ \\
Total protein (g/dl) & $6.8 \pm 0.3$ & $6.4 \pm 0.2$ & $6.6 \pm 0.2$ \\
Globulin (g/dl) & $2.4 \pm 0.2$ & $2.2 \pm 0.2$ & $2.0 \pm 0.1$ \\
Albumin (g/dl) & $4.4 \pm 0.6$ & $4.4 \pm 0.1$ & $4.3 \pm 0.1$ \\
Albumin / Globulin & $2.0 \pm 0.1$ & $2.1 \pm 0.1$ & $2.2 \pm 0.1$ \\
Urea (mg/dl) & $55.7 \pm 5.1$ & $51.5 \pm 5.8$ & $53.5 \pm 2.3$ \\
Glucose (mg/dl) & $113.0 \pm 16.4$ & $96.1 \pm 10.2$ & $93.6 \pm 8.2$ \\
ALT (IU) & $52.4 \pm 4.7$ & $45.3 \pm 3.7$ & $43.8 \pm 3.1$ \\
AST (IU) & $60.0 \pm 13.7$ & $65.2 \pm 14.3$ & $59.2 \pm 8.8$ \\
ALP (IU) & $38.6 \pm 3.2$ & $39.5 \pm 2.6$ & $41.8 \pm 2.3$ \\
\hline
\end{tabular}

ALT, Alanine aminotransferase; AST,Aspartate aminotransferase. ALP, Alkaline Phosphatase; Nawb, Whole blood $\mathrm{Na}^{+}$concentrations; $\mathrm{K}_{\mathrm{wb}}$,Whole blood $\mathrm{K}^{+}$concentrations.

Table 3. Haematological Indices of rabbits in Control and Experimental Groups (mean \pm SE, $n=30)$.

Tablo 3. Kontrol ve Deney gruplarının hematolojik değerleri (ortalama \pm standart hata, $\mathbf{n = 3 0}$ )

\begin{tabular}{|c|c|c|c|}
\hline \multirow{3}{*}{$\begin{array}{l}\text { Haematological } \\
\text { Indices }\end{array}$} & \multicolumn{3}{|l|}{ Yeast (g/kg) } \\
\hline & 0 & 2 & 4 \\
\hline & Control & Treatment 1 & Treatment 2 \\
\hline Haemoglobin (g/dl) & $10.9 \pm 0.6$ & $12.1 \pm 0.6$ & $12.1 \pm 0.7$ \\
\hline Haematocrit (\%) & $39.0 \pm 2.8$ & $42.0 \pm 2.6$ & $42.0 \pm 1.8$ \\
\hline Erythrocyte (106/ul) & $6.1 \pm 0.2$ & $6.6 \pm 0.5$ & $6.0 \pm 0.5$ \\
\hline Leukocyte (103/ul) & $6.7 \pm 0.8$ & $.9 \pm 0.7$ & $7.3 \pm 0.8$ \\
\hline $\mathrm{MCV}^{1}(\mathrm{FL})$ & $65.1 \pm 6.1$ & $64.1 \pm 3.8$ & $73.5 \pm 2.7$ \\
\hline $\mathrm{MCH}(\mathrm{pg})^{\prime}$ & $18.1 \pm 1.3$ & $18.8 \pm 1.0$ & $21.4 \pm 1.1$ \\
\hline $\mathrm{MCHC}(\%)$ & $28.4 \pm 0.9$ & $29.5 \pm 0.6$ & $29.0 \pm 0.7$ \\
\hline $\begin{array}{l}\text { GSH² (mg/dl } \\
\text { erythrocytes) }\end{array}$ & $99.2 \pm 4.8$ & $106.6 \pm 5.7$ & $101.4 \pm 5.9$ \\
\hline Lymphocytes² & $72.0 \pm 4.9$ & $63.8 \pm 3.7$ & $63.1 \pm 6.0$ \\
\hline Neutrophils ${ }^{2}$ & $23.5 \pm 5.1$ & $28.7 \pm 3.6$ & $28.5 \pm 5.9$ \\
\hline Eosinophils² & $1.1 \pm 0.3$ & $2.5 \pm 0.5$ & $1.6 \pm 0.4$ \\
\hline Monocytes² & $3.3 \pm 0.4^{a}$ & $5.0 \pm 0.5^{b}$ & $4.5 \pm 0.4^{b}$ \\
\hline Basophils² & $1.0 \pm 0.2$ & $0.4 \pm 0.2$ & $0.9 \pm 0.2$ \\
\hline
\end{tabular}

$\mathrm{MCV}$, mean corpuscular volume; $\mathrm{MCH}$, mean corpuscular haemoglobin; MCHC, mean corpuscular haemoglobin concentration; GSH, Gulutathione ${ }^{2}$ Leukocyte differentials are expressed as percentage of the total cells count.

Different superscripts a, b, show differences $(\mathrm{p}<0.05)$ between groups.

Gruplar arasında farklılıklar a, b ile gösterilmiştir $(\mathrm{p}<0.05)$ 


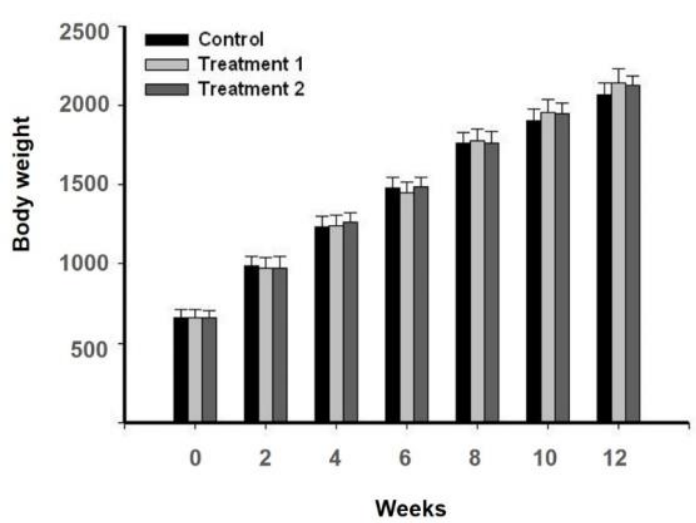

Figure 1. Body weight of rabbits in Control and Experimental Groups ( $\mathrm{g}$ ).

Şekil 1. Kontrol ve Deney gruplarınin canlı ağırlıkları $(g)$

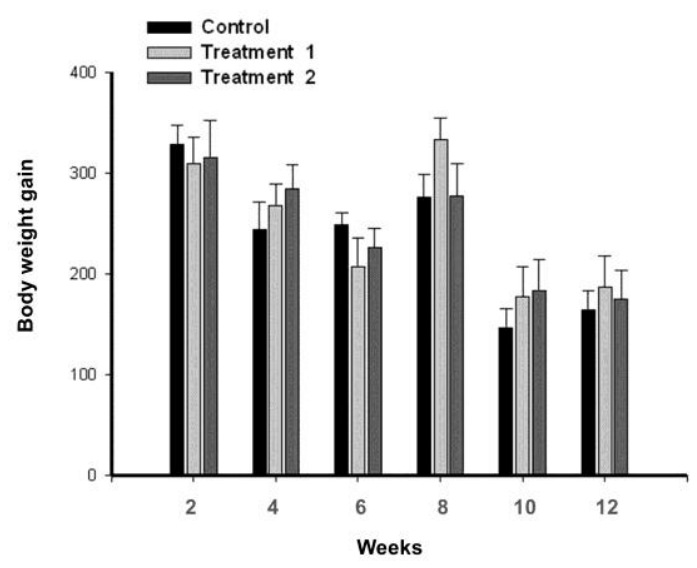

Figure 2. Body weight gain of rabbits in Control and Experimental Groups $(g)$.

Şekil 2. Kontrol ve Deney gruplarının canl ăgırlık kazançları (g)

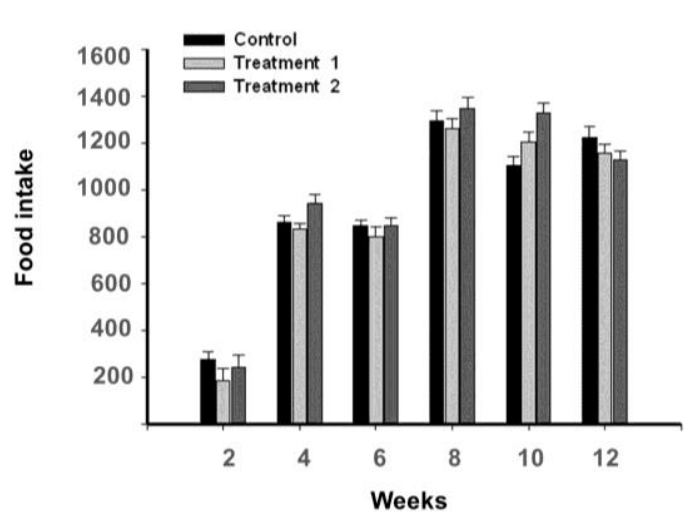

Figure 3. Food intake of rabbits in Control and Experimental Groups ( $\mathrm{g}$ ).

Şekil 3. Kontrol ve Deney gruplarının yem tüketimi (g)

\section{Discussion}

There is an increasing demand to use the alternative supplements in animals feeding, especially for improving the growth performances. The present study is an experiment to identify the effects of $S$. cerevisiae for rabbits. According to the results of this study, body weight, body weight gain and food intake of rabbits were not significantly affected by dietary $S$. cerevisiae supplementation $(\mathrm{p}>0.05)$. This confirmed the previous findings of several researchers ${ }^{22,25}$. However, the mechanisms of growth performances by yeast in rabbits, turkey poults and broiler chickens was reported ${ }^{1,14,33}$.

S. cerevisiae is known as a good probiotic for promote the performance and health of animals. In the present study, the haemotological and biochemical values were found in normal reference ranges in rabbits ${ }^{20,42}$. As far as haematological parameters were concerned, no significant variations in experimental groups could be noticed, although haematocrit and haemoglobin concentration tended to be increased in rabbits supplemented with yeast. Unchanged haemoglobin, haemotocrit, erythrocyte, $\mathrm{MCV}, \mathrm{MCH}$, $\mathrm{MCHC}$ in broiler chicks fed diets with probiotics are supported by the findings of other researchers ${ }^{17,33,36}$. However, Onifade et al. ${ }^{29}$ reported that haematocrit, haemoglobin, $\mathrm{MCV}$ and $\mathrm{MCH}$ increased significantly $(\mathrm{p}<0.05)$ by dietary S. cerevisiae in rabbits. These results do not agree with the present study. This may be due to such differences in dose of $S$. cerevisiae. On the other hand, decrease in haematocrit value $(p<0.01)$ in dairy cows as a result of increased protein requirement because of increased yields of milk by dietary $S$. cerevisiae has been documented by Wohlt et al. ${ }^{41}$.

The immunoregulatory functions of monocytes are crucial in both humoral ${ }^{32,34}$ and cellular ${ }^{40}$ immunity. In addition, yeast and yeast cell wall glucans effectively activate the monocyte $^{6,8,11,35,37}$. In this study, although there was no significant variations, leukocyte value tended to be increased in rabbit fed by yeast ( $p>0.05$ ). The differential counts of leukocytes were different as exemplified by the higher populations of monocytes $(\mathrm{p}<0.05$, Table 3 ) in rabbits fed the $2 \mathrm{~g} / \mathrm{kg}$ and $4 \mathrm{~g} / \mathrm{kg} \mathrm{S}$. cerevisiae treatment. Increased monocyte value in rabbits fed yeast, may be due to supporting the immune system. Supporting our results, Harnack et al. ${ }^{18}$ observed stimulatory effect of $\beta$-glucan derived from the inner cell wall of $S$. cerevisiae on 
monocytes. They demonstrated that an orally administered soluble $\beta$-glucan accelerates the recovery of monocytes in the peripheral blood in leukopenic mice. Consequently, some components of natural and induced immunity may be expressed to determine.

Although statistically not significant, the serum cholesterol value tended to be decreased in treatment 2 ( $p>0.05)$. Similary, Ozsoy et al..$^{30}$ and Y1ldiz et al. ${ }^{43}$ found no significant differences in serum cholesterols fed by yeast in broilers. However, data published by Shrivastava and $\mathrm{Jha}^{38}$ and Onifade et al. ${ }^{29}$, who stated that there was a significant decrease $(p<0.05)$ in plasma cholesterol by dietary yeast. Cholesterol is precursor of bile acid, hence more molecules are spent for recovery of bile acids. Probiotics are known to metabolize bile salts, bile acids and prevent reabsorption and recirculation of bile acids into blood. In this way, probiotics could contribute to the regulation of serum cholesterol concentrations by deconjunction of bile acids. Use of probiotics lead to increased excretion of deconjugated bile acids. ${ }^{10}$. As a result of increased synthesis of this acid, the level of serum cholesterol gets reduced. Also, Klaver and Van Der Meer ${ }^{23}$ suggested that coprecipitation with bile acids might be of importance for decreasing of serum cholesterol concentrations. Furthermore, the addition of innocuous microorganisms including yeast to diets of rats and broiler chickens decreased serum cholesterol, triglycerides, phospholipids and abdominal $\mathrm{fat}^{15}$. Compared with the above results, the insignificant differences in the present study may be due to the lower dose of S. cerevisiae.

No significant differences among the treatments were observed in serum minerals (calcium, phospohours, potassium, sodium) in recent study. Similar results were confirmed by some researchers ${ }^{16,36,38}$. The present datas suggest that $S$. cerevisiae does not have any positive or negative effect on mineral metabolism. Nevertheless, ALT, AST and ALP of rabbits were not influenced by different value of $S$. cerevisiae. On the other hand, concentration of serum proteins, glutathione and urea in serum of rabbits were not differ among treatments groups.

It is well known that monocytes are capable of producing several important mediators involved in immunity. In this research, despite there was insignificant increase in leukocyte value, monocyte had a significant increase $(\mathrm{p}<0.05)$. Increased monocyte value may be beneficial to improving the immunity. More studies are necessary to obtain the effects of the higher dose of yeast supplementation on the immunological reactions, haemotological and biochemical parameters and growth performances.

\section{Acknowledgment}

This study was supported by grant from the Research Foundations of Uludag University (2008/65).

\section{References}

1. Abou El- Naga, M.K. 2012. Effect Of Dietary Yeast Supplementation On Broiler Performance. Gypt. Poult. Sci., 32 (1), 95-106.

2. Association of official Analytical Chemists. 1990. Official Methods of Analysis, AOAC, Arlington, YA.

3. Ashayerizadeh, A., Dabiri, N., Mirzadeh, K.H., Ghorbani, M.R. 2011. Effect of dietary supplementation of probiotic and prebiotic on growth indices and serum biochemical parameters of broiler chickens. Journal of Cell and Animal Biology, 5(8), 152-156.

4. Bekatorou, A., Psarianos, C., Koutinas, A.A. 2006. "Production of Food Grade Yeasts". Food Technology Biotechnology, 44, 407-415.

5. Beutler, E., Duron, O., Kelly, B.M. 1963. Improved method for the determination of blood glutathione. J. Lab. Clin Med., 61, 882-8.

6. Bogwald, J., Gouta, I., Hoffman, J., Larm, 0., Larsson, R., Seljelid, R. 1984. Stimulatory effect of immobilized glycans on macrophages in vitro. Scand. J. Immunol., 20, 355.

7. Cannon, R.K. 1958. Haemoglobin (as Cyanmethemoglobin) in blood. Clin.Chem, 4, 246251.

8. Carpenter, K.C., Breslin, W.L., Davidson, T., Adams, A. and McFarlin, B.K. 2012. Baker's yeast $\beta$-glucan supplementation increases monocytes and cytokines post-exercise: implications for infection risk? British Journal of Nutrition, $10,1-9$.

9. Dawson, B., Trapp, R.G. 2001. Basic and Clinical Biostatistics, 3rd Ed., Lange Medical Books/McGraw International Editions, New York.

10. De Smet, I., Van Hoorde, L., De Saeyer, N., Vande Woestyne, M., Verstraete, W. 1994. In Vitro Study of Bile Salt Hydrolase (BSH) Activity of BSH Isogenic Lactobacillus plantarum 80 Strains and Estimation of Cholesterol Liwering through Enhanced BSH Activity. Microbial Ecology in Health and Disease, 7 (3), 315-329. 
11. Doita, M., Rasmussen, L.T., Seljelid, R., Lipsky, P.E. 1991. Effect of Soluble Aminated $\beta$-1,3-DPolyglucose on Human Monocytes: Stimulation of Cytokine and Prostaglandin E2 Production but Not Antigen-Presenting Function. Journal of Leukocyte Biology, 49, 342-351.

12. Dowdy, S., Wearden, S. 1981. Statistics for Research. John Wiley \& Sons, New York. Pp, 262 274.

13. El-Arab, A.E., Foheid, S., El-Said, M. 2009. Effect of yeast and botanical $\beta$-glucan on serum lipid profile and cecum Probiotic bacteria using rats fed cholesterol diet. Pol. J. Food Nutr Sci., 59 (2), 169-174.

14. Ezema, C., Eze, C.D. (2010). Determination of the effect of probiotic (Saccharomyces cerevisiae) on growth performance and hematological parameters of rabbits. Comp. Clin. Pathol., 21, 73-76.

15. Fukushima, M., Nakano, M. 1996. Effects of a mixture of organisms, Lactobacillus acidophilus or Streptococcus faecalis on cholesterol metabolism in rats fed on a fat- and cholesterol-enriched diet. Br J Nutr. Dec., 76 (6): 857-67.

16. Galip, N. 2006a. Effect of supplemental yeast culture on ruminal protozoa and blood parameters in Rams. Revue Med. Vet., 157, (11), 519524.

17. Gheisari, A., Kholeghipour, B. 2008. Effect of dietary inclusion of live yeast (Saccharomyces cerevisiae) on growth performance, immune responses and blood parameters of broiler chickens. Revista electronica de Veterinaria, 9: 1695-7504.

18. Harnack, U., Eckert, K., Fichtner, I., Pecher, G. 2010. Comparison of the effect of orally administered soluble beta-(1-3), (1-6)-D-glucan and of $\mathrm{G}-\mathrm{CSF}$ on the recovery of murine hematopoiesis. In Vivo, 24 (1): 59-63.

19. Hassanein, M.S., Soliman, N.K. 2010. Effect of Probiotic (Saccharomyces cerevisiae) Adding to Diets on Intestinal Microflora and Performance of Hy-Line Layers Hens. Journal of American Sci., 6 (11), 159-169.

20. Hewitt, C.D., Innes, D.J., Savory, J., Wills, M.R. (1989). Normal biochemical and hematological values in New Zealand White Rabbits. Clin.Chem., 35 (8), 1777-1779.

21. Jain, N.C. (1986). Schalm's Veterinary heamatology. 4th Ed. Lea \& Febiger, Philadelphia, pp, 3536.

22. Kimsé, M., Bayourthe, C., Monteils, V., Gidenne, T. 2008. Live Yeast Stability In The Digestive Tract Of The Rabbit: Relationship With Digestion, Growth And Digestive Health. Nutrition and Digestive Physiology. 9th World Rabbit Congress. June 10-13. Verona, Italy, pp, 695-700.
23. Klaver , F.A.M., Van Der Meer, R. 1993. The Assumed Assimilation of Cholesterol by Lactobacilli and Bifidobacterium bifidum Is Due to Their Bile Salt-Deconjugating Activity. Applied and Environmental Microbiology Apr., 59(4), 1120-1124.

24. Kumar, D.S., Prasad, J.R., Rao, E.R. 2011. Effect of Dietary Inclusion of Yeast Culture (Saccharomyces Cerevisiae) on Growth Performance of Graded Murrah Buffalo Bull Calves. Buffalo Bulletin, 30 (1), 63-66.

25. Maertens, L., De Groote, G. 1992. Effect of a dietary supplementation of live yeast on the zootechnical performances of does and weanling rabbits. J. Appl. Rabbit Res., 15, 1079-1086.

26. Milewski, S., Zaleska, B. 2011. The effect of dietary supplementation with Saccharomyces cerevisiae dried yeast on lambs meat quality. Journal of Animal and Feed Sciences, 20, 537545.

27. National Research Council (NRC). 1977. Nutrient Requirements of Rabbits. 6th Ed. National Academy Press, Washington.

28. Onifade, A.A. 1997. Growth performance, Carcass characteristies, Organ measurements and haematology of broiler chickens fed a high fibre diet supplemented with antibiotics or dried yeast. Die Nahrung, 41, 370-374.

29. Onifade, A.A., Obiyan, R.I., Onipede, E., Adejumo, D.O., Abu, O.A., Babatunde, G.M. 1999. Assessment of the effects of supplementing rabbit diets with a culture of Saccharomyces cerevisiae using growth performance, blood composition and clinical enzyme activities. Anim. Feed Sci. Tech,. 77, 25-32.

30. Ozsoy, B., Yalçın, S. 2011. The effects of dietary supplementation of yeast culture on performance, blood parameters and immune system in broiler turkeys, Ankara Univ Vet Fak Derg., 58, 117122.

31. Ponce, C. H., Schutz, J. S., Elrod, C. C., Anele, U. Y., Galyean M. L. 2012. Effects of dietary supplementation of a yeast product on performance and morbidity of newly received beef heifers, Professional Animal Scientist, 28, 618622.

32. Rosenberg, S.A., Lipsky, P.E. 1979. Monocyte dependence of pokeweed mitogen-induced differentiation of immunoglobulin secreting cells from human peripheral blood mononuclearcells. J. Immunol., 122, 926.

33. Saied, J.M., Al-Jabary, Q.H., Thalij, K.M. 2011. Effect of Dietary Supplement Yeast Culture on Production Performance and Hematological Parameters in Broiler Chicks. International Journal of Poultry Science, 10 (5), 376-380.

34. Saxon, R.A., Stevens, R.H. 1978. Suppression of immunoglobulin production in normal human 
blood: Characterization of the cells responsible and mediation by a soluble $\mathrm{T}$ lymphocyte-derived factor. Clin. Immunol. Immunopathol., 10, 427.

35. Seljelid, R., Bogwald, J., Hoffman, J., Larm, 0.A. 1984. Soluble $\beta$-1 ,3-D-glucan derivative potentiates the cytostatic and cytolytic capacity of mouse peritoneal macrophage in vitro. Immunopharmacology, 7, 69.

36. Shareef, A.M., Al-Dabbagh, A.A.S. 2009. Effect of probiotic (Saccharomyces cerevisiae) on performance of broiler chicks. Iraqi Journal of veterinary Science, 23 (Supll. 1), 23-29.

37. Sherwood, E.R. 1986. Williams, DR., DiLuzio. NR. 1986. Glucan stimulates production of antitumor cytotoxic/cytostatic factor by macrophages. J. Biol. Response Modifiers, 5, 504.

38. Shrivastava, A.K., Jha, R.R. 2010. Effects Of Different Chemical Composition And Probiotic On The Haematobiochemical Profile Of Rabbit. EJEAFChe, 9 (9), 1507-1513.

39. SPSS. SPSS software package for Windows, Version 17.0, Chicago.
40. Wagner, H., Feldmann, M., Boyle, W., Schrader, J.W. 1972. Cell mediated immune response in vitro. III. The requirement for macrophages in cytotoxic reactions against cell-bound and subcellular alloantigens. J. Exp. Med., 136, 331.

41. Wohlt, J.E., Corcione, T.T., Zajac, P.K. 1997. Effect of yeast on feed intake and performance of cows fed with diets based on corn silage during early lactation. Journal of Dairy Science, 81, 1345-1352.

42. Wolford, S.T., Schroer, R.A., Gohs, F.X., Gallo, P.P., Brodeck, M., Falk, H.B., Ruhren, R. 1986. Reference range data base for serum chemistry and hematology values in laboratory animals. Journal of Toxicology and Environmental Health, 18, 161-188.

43. Yıldız, G., Köksal, B.H., Sizmaz, O. 2011. Effects of Dietary Boric Acid and Yeast (Saccharomyces cerevisiae) Supplementation on Performance, Carcass Traits and Some Blood Parameters of Broilers. Kafkas Univ Vet Fak. Derg., 17 (3), 429-434. 
